\title{
KINERJA HUBUNGAN MASYARAKAT (HUMAS) PEMERINTAH DAERAH KABUPATEN DAN KOTA DI JAWA BARAT
}

\author{
Agus Rahmat dan Iriana Bakti \\ Universitas Padjadjaran
}

\begin{abstract}
ABSTRAK
Kebutuhan pemerintah Indonesia atas Humas pemerintah tidak lagi dalam tataran wacana atau sekedar konsep secara kellmuan, keberadaan Humas pemerintah didorong atas kebutuhan pemerintah untuk menjelaskan apa yang dilakukan oleh pemerintah kepada ,asyarakat guna memperoleh dukungan dan untuk menerangkan apa dan bagaimana yang dilakukan pemerintah sehingga lingkungan masyarakat dalam dan masyarakat luar percaya. sudah sejak lama pemerintah di Indonesia termasuk pemerintah daerah memiliki Humas pemerintah, bahkan khusus di lingkungan pemerintah, profesi ini tergabung dalam wadah BakoHumas. Fakta yang ada dan berkembang mengisyaratkan sekaligus mempertanyakan mengenai kinerja Humas Pemerintah selama ini. Penelitian ini dilakukan dengan tujuan untuk mendeskripsi kinerja Humas pemerintah khususnya Humas Pemerintah kabupaten dan kota di Jawa Barat. Untuk mencapai tujuan penelitian, metode yang digunakan adalah deskriptif dengan teknik pengumpulan data dilakukan melalui penyebaran angket. Temuan dari penelitian ini memperlihatkan bahwa: pertama, kinerja Humas pemerintah lebih banyak menerimaan teguran dibanding pujian/penghargaan atas hasil kerja; kedua, pegawai di bagian Humas pemerintah sangat sedikit yang berlatar belakang pendidikan formal komunikasi, terlebih lulusan keHumasan selain itu pegawai juga jarang mendapat pendidikan non formal bidang keHumasan; ketiga, aktivitas Humas pemerintah lebih tertumpu pada kegiatan rutin berupa penyediaan informasi bagi media. Konsekuens dari temuan penelitian ini adalah perlunya pengembangan kompetensi pegawai Humas pemerintah melalui linieritas bidang kerja dan pendidikan bagi pegawai baru dan pelatihan bidang keHumasan bagi petugas yang sudah ada.
\end{abstract}

Kata-kata kunci: Humas pemerintah, kinerja, profesi, kompetensi, bidang kerja

\section{PERFORMANCE OF GOVERNMENT PUBLIC RELATIONS IN WEST JAVA}

\section{ABSTRACT}

The Indonesia government's need of Government Public Relations has not been in a discourse level or just a scientific concept, it should be reinforced by the government's need to explain what they had done to the people to gain their supports and to inform how and what had been done so theywould be trusted by internal and external society. It has been long time that the governments of Indonesia, including local governments, has had government public relations, and even especially the government public relations officers, they are bonded in an organization called BAKOHUMAS (Coordinator Institute of Government Public Relations).Existing and developing facts have symbolizing and at the same time, questioning about the government public relations during this time. This research is aiming to describe the performance of government public relations, especially the government public relations in the cities and residences of Jawa Barat (West Java Province).To achieve its objectives, and the method used is descriptive with questionnaires distribution as data collection technique.

The results show that, firstly, the government public relations officers have received more critics rather than compliments/ appreciations as their performances; secondly, there are only few public relation officers who have communication, especially public relations formal education background, and moreover, the officers have rarely got non formal training of public relations; thirdly, the government public relations activities is more focused on routine activities, such as, providing information for the media. The consequences of this unveiled condition are that there should be competency improvements for the officers through education background and working field linearity for new staffs, and training of public relations skills for the existing staffs.

Keywords: Government public relations, performance, profession, competency, work field

Korespondensi: Dr. Agus Rahmat, M.Pd. Fakultas Ilmu Komunikasi Universitas Padjadjaran. Jl. Raya BandungSumedang KM.21 Jatinangor, 45363.Email: agusrahmat.fikom@gmail.com 


\section{PENDAHULUAN}

Perubahan paradigma manajemen pemerintahan sejakeraotonomidaerahtelahmembawa konsekwensi pada perubahan orientasi dalam sistem pemerintahan di Indonesia. Beberapa orientasi yang dapat dicermati adalah: orientasi yang berasal dari layanan publik ke arah orientasi market; orientasi sentralistik ke desentralistik; orientasi media pelayanan ke tujuan pelayanan.

Seiring dengan dinamika masyarakat yang semakin cepat dan juga euporia demokrasi semenjak jaman reformasi yang berlanjut sampai saat ini, kondisi ini telah menimbulkan berbagai masalah sosial dan perubahan ketatanegaraan yang harus dihadapi oleh pemerintah Indonesia dengan segenap unsurnya termasuk pemerintahan di daerah. Salah satu pemerintah daerah yang mengalami kondisi ini adalah Jawa Barat.

Bagi pemerintah di daerah, tentunya penting untuk mengantisipasi berbagai perubahan yang muncul seperti tuntutan publik internal dan publik eksternal yang semakin tinggi. Euporia kehidupan pers, jaminan atas kebebasan masyarakat untuk memperoleh informasi publik atas jalannya pemerintah dan pemerintahan, sampai ke tindakan anarkis masyarakat.

Semua itu memerlukan pendekatanpendekatan yang berbeda dengan jaman dulu, jaman yang mengandalkan "power" menjadi pendekatan yang lebih menekankan pada "personal aproach dan relationship", dan salah satu instutusi yang memiliki fungsi erat dengan ini adalah Hubungan Masyarakat (Public Relations (PR)).

Persoalan yang muncul adalah, perubahanperubahan ini seringkali tidak diimbangi dengan peningkatan kemampuan aparat pemerintah guna mengimbangi perubahan tersebut. Maka menjadi tidak heran jika mulai dari presiden Republik Indonesia dan wakilnya mengatakan bahwa "juru bicara dan hubungan masyarakat pemerintah tidak mampu mengantisipasi dan menjawab perubahan". Empat tahun kemudian, kondisi mengenai kekurangmampuan hubungan masyarakat pemerintah untuk meningkatkan diri guna mengikuti perubahan yang terjadi nampaknya tidak banyak berubah. Kondisi mengenai kinerja pemerintah yang kurang ini juga kembali baik oleh presiden Susilo
Bambang Yudoyono, Muhammad Nuh, Menpan Taufiq Effendi dan Mendagri $\mathrm{H}$ Mardiyanto yang diwakili Dirjen Otda Kausar AS pada pertemuan tahunan tingkat nasional Badan Koordinasi KeHumasan (BakoHumas) di Kuta, Bali (Kompas, 18 Desember 2006).

Untuk lingkungan departemen ataupun lingkup dinas, kinerja hubungan masyarakat pemerintah juga berada pada kondisi yang sama, hal ini bisa dilihat dari apa yang dikemukakan menteri Hukum dan Hak Azasi Manusia Republik Indonesia yang mengatakan bahwa "Kinerja Humas pemerintah, khususnya Departemen Hukum dan HAM masih bisa dikembangkan lebih baik lagi. Bila diibaratkan dengan pertandingan olahraga, Humas belum menampilkan permainan terbaik. Akibatnya para pemain masih canggung dalam bertanding dilapangan. Kinerja yang terlihat masih jauh dari maksimal" (Setiawan, 2009).

Persoalan yang muncul dari deskripsi sebagaimana dikemukakan di atas adalah, apakah kondisi dari kinerja hubungan masyarakat pemerintah di atas berlaku atau terjadi juga pada pemerintah daerah yang ada di wilayah Jawa Barat?

Persoalan ini menjadi penting untuk dijawab karena adanya beberapa alasan diantaranya:(1)Pemberlakuan otonomi daerah telah membawa konsekuensi yang berupa kewenangan dan kebebasan pemerintah daerah untuk mengatur dan mengurus rumah tangganya dalam mencapai tujuan kehidupan bernegara yang lebih baik dan cepat, sehingga kreativitas ataupun inovasi pemerintah daerah termasuk perubahan dan pengembangan strategi dasar (the core strategy) menjadi sangat besar, hal ini sangat berbeda jauh dibanding ketika Indonesia menerapkan sistem yang sentralistis, (2) Berdasarkan visi yang dimiliki, Jawa Barat mencanangkan diri sebagai provinsi termaju, (3) Sejak tahun 2007, melalui Peraturan menteri No. 12/M. PAN/08/Tahun 2007 Hubungan masyarakat pemerintah telah memiliki panduan yang jelas sampai pada kompetensi dan tingkat pendidikan untuk pemangku jabatannya.

Berdasarkan atas apa yang dideskripsikan sebelumnya maka penelitian mengenai kinerja hubungan masyarakat pemerintah daerah di Jawa Barat menjadi hal yang amat penting untuk diteliti dan penelitian ini merupakan 
upaya untuk menjawab permasalahan dalam penelitian ini.

Untuk menjawab masalah utama, lingkup dari penelitian ini yaitu: (1) Gambaran dan analisis profil pendidikan formal dan non formal petugas hubungan masyarakat pemerintah daerah di Jawa Barat, (2) Gambaran dan analisis bidang kerja utama hubungan masyarakat pemerintah di Jawa Barat, (3) Alisis kinerja petugas Humas pemerintah

Ada dua teori atau model dalam penelitian ini yang menjadi pijakan terkait dengan kinerja pegawai, yaitu model motivasi dan kinerja (model of motivation and performance) dari Mitchell and Larson (1987) serta Hackman and Oldham's dalam Mitchell and Larson (1987) mengenai job characteristics model of job enrichment.

Dalam teori model of motivation and performance disebutkan bahwa salah satu faktor yang menentukan "perilaku nyata" seorang pegawai adalah aspek kemampuan dan pengetahuan (ability and knowledge) (1987: 153)

Model Hackman and Oldham's job characteristics model of job enrichment dipakai dalam kaitan dengan kualitas pekerjaan yang ditampilkan. Menurut model ini disebutkan bahwa salah satu yang menentukan tingginya kinerja (high-quality work performent) adalah arti dari pekerjaan tersebut bagi pekerja, dan arti dari pekerjaan bagi seseorang dasarnya ditentukan oleh tingkat keterampilan pekerja, kejelasan tugas serta kebermaknaan dari tugas atau pekerjaan. (1987: 175).

Konsep penelitian terkait dengan bidang kerja Humas, digunakan hasil dari Gold paper InternationalPublicRelationsAsociation(IPRA), dalam Nuradi dari Bunga Rampai KeHumasan, yang mencakup atas: (1) Memberi koseling, (2) Membuat analsisis dan kecenderungan masa depan, (3) Riset sikap, pendapat dan harapan, (4) Membina dan menciptakan komunikasi dua arah, (5) Mencegah konflik, (6) Meningkatkan rasa saling hormat, (7) Melakukan penyerasian kepentingan, (8) Meningkatkan pengalaman itikad baik lembaga, (9) Memperbaiki hubungan industrial, (10) Menarik calon tenaga yang baik, (11) Memasyarakatkan produk dan layanan,(12) Mengusahakan perolehan laba maksimal, (13) Menciptakan identitas, (14) Memupuk minat mengenai masalah-masalah nasional maupun internasional, (15) Meningkatkan pengertian mengenai demokrasi

\section{METODE}

Bailey mengartikan metode sebagai alat dalam mendapatkan data atau "...By "method" we simply mean the research technique or tool used to gather data.." (1987: 32-33). Penggunaan metode dalam suatu penelitian menurut Hidayat (2002) merupakan implikasi dari pendekatan/paradigma yang dipergunakan oleh peneliti. Bagi ahli lain seperti Yin, penggunaan metode penelitian ditentukan oleh (1) tipe pertanyaan penelitian, (2) kontrol yang dimiliki peneliti terhadap peristiwa perilaku yang akan diteliti, dan (3) fokus terhadap fenomena penelitiannya (2002: 1).

Atas dasar pert imbangan tujuan yang mau dicapai penelitian seperti yang telah dirumuskan, maka peneliti menggunakan metode penelitian kualitatif melalui survei dan wawancara, oleh karena itu beberapa data yang terkumpul akan bersifat kuantitatif.

Untuk mencapai efisiensi namun tanpa mengurangi kualitas secara ilmiah, penelitian dilakukan di tiga kabupaten yang mencakup atas; (1) satu kabupaten yang masuk sebagai daerah industri, (2) satu kabupaten mengarah sebagai daerah industri, serta satu kabupaten yang baru dan kecil wilayah industrinya.

Dalam penelitian ini data diperoleh berdasarkan atas beberapa sumber bukti yang berlainan yaitu: dokumen, angket, arsip, dan wawancara.

Berdasar pada pertimbangan mengenai keterbatasan dari observasi, yaitu adanya ketidak mampuan dalam mengungkap apa yang dirasakan orang lain, maka dalam penelitian inipun peneliti menggunakan angket dan wawancara.

Wawancara yang dilakukan peneliti mencakup atas tiga pendekatan seperti diungkap Nasution (1992) yaitu: (1) Dalam bentuk pendekatan informal, yang mengandung unsur spontanitas, kesantaian, tanpa pola atau arah yang ditentukan sebelumnya, (2) Menggunakan lembar berisi garis besar pokok-pokok, topik atau masalah yang dijadikan pegangan dalam pembicaraan, (3) Menggunakan daftar pertanyaan yang lebih rinci, namun bersifat 
terbuka yang telah dipersiapkan lebih dahulu dan akan diajukan menurut urutan dan rumusan yang tercantum.

\section{HASIL DAN PEMBAHASAN}

Penelitian ini dilaksanakan pada tiga daerah kabupaten yang meliputi Kabupaten Karawang, Sukabumi dan Kabupaten Pangandaran.

Jumlah pegawai di bagian hubungan masyarakat pemerintah di wilayah kajian bervariatif. Ada yang sembilan (9) orang dan ada juga kabupaten yang memiliki pegawai sebanyak tiga belas orang.

Dilihat dari tingkat pendidikan, komposisi pendidikan pegawai Humas di derah kajian dimulai dari mereka yang berpendidikan sekolah menengah atas sampai mereka yang berpendidikan sarjana. Komposisi pendidikan pegawai hubungan masyarakat, di wilayah kajian ditunjukan melalui Gambar 1.

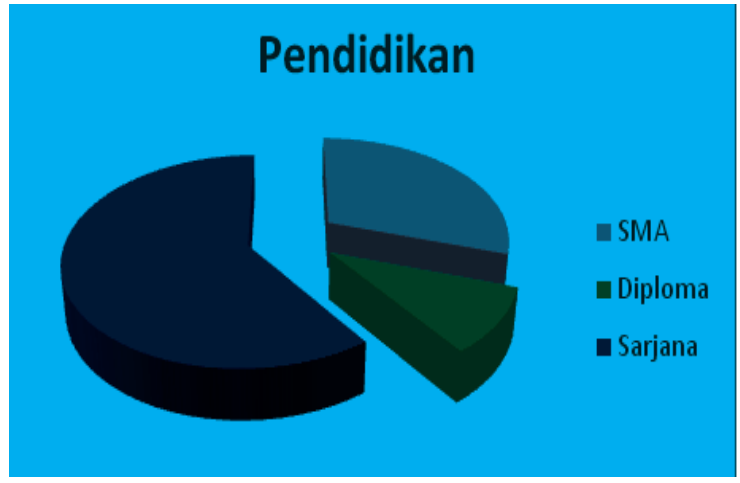

Gambar 1 Tingkat Pendidikan Pegawai Humas Pemerintah

Gambar 1 menunjukkan bahwa berdasarkan jenjang pendidikan, kebanyakan pegawai Humas di pemerintah kabupaten berada pada tingkat pendidikan tinggi (sarjana). Ini berarti bahwa berdasarkan jenjang pendidikan, sesungguhnya pegawai Humas di pemerintah daerah sudah memiliki modal yang cukup untuk berkinerja atau produktivitas yang tinggi, dengan dasar pemikiran bahwa tingkat pendidikan berkontribusi dengan kompetensi, sehingga pada akhirnya akan berkorelasi juga dengan tingkat kinerja.

Demikian banyak pendapat para ahli dan hasil riset yang menunjukan korelasi diantara pendidikan dengan kinerja atau produktivitas baik bagi individu yang bersangkutan maupun bagi masyarakatnya, salah satu pendapat seperti dikutip Rahmat dari Supriyatna (2008) bahwa "memang menjadi tujuan akhir dari pendidikan adalah terciptanya produktivitas, etos kerja, kemandirian, dan jati diri manusia yang unggul untuk memenuhi tuntutan pembangunan.

Menentukan tingkat produktivitas bisa dilihat dalam pemikirannya Inkeles dalam Sparks (2007) bahwa "lamanya seseorang mengenyam pendidikan sekolah merupakan prediktor yang konsisten dan powerful terhadap sikap, nilai-nilai, dan perilaku seseorang". Atau hasil penelitian Von Thunen, yang menunjukan bahwa "seseorang yang memperoleh pendidikan lebih tinggi dapat meningkatkan keterampilan dan kemampuannya...." (Anwar, 2014).

Berdasarkan pemikiran dan data hasil riset Unesco Djoyonegoro sebagaimana dikutip Rahmat (2008) mengatakan bahwa "Oleh karena itu, menjadi hal yang tidak mengherankan apabila banyak negara melakukan investasi dalam dunia pendidikan."

Apabila berdasarkan jenjang pendidikan, tenaga Humas pemerintah sudah memiliki modal yang sudah baik berupa tingkat jenjang pendidikan yang mayoritasnya tinggi, persoalan selanjutnya adalah apakah latar belakang bidang keIlmuan pegawai memiliki relevansi dengan bidang kerja. Data latar belakang bidang keIlmuan dengan pekerjaan ditunjukkan melalui data Gambar 2.

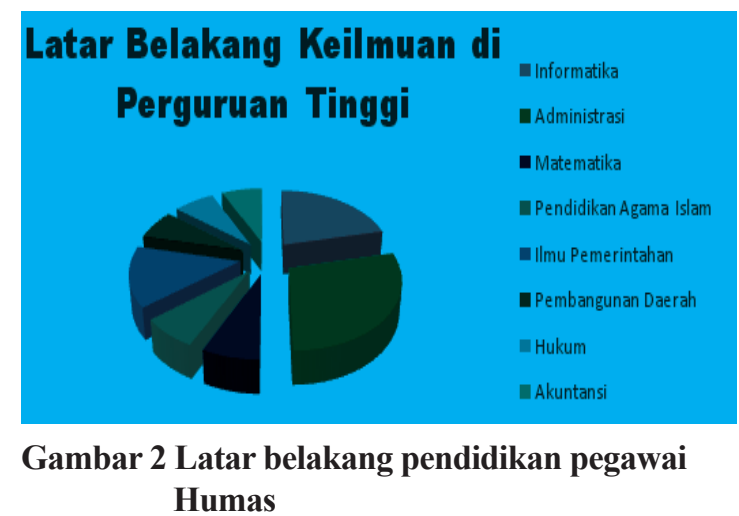

Gambar 2 memperlihatkan bahwa dari mayoritas pegawai Humas yang berasal dari pendidikan tinggi, tidak satupun berlatar belakang komunikasi terlebih berlatar belakang berpendidikan Program studi KeHumasan.

Pegawai di bagian hubungan masyarakat paling banyak berlatar belakang pendidikan Administrasi Negara, disusul dengan informatika, kemudian Ilmu Pemerintahan baru kemudian 
sarjana yang berlatar belakang Ilmu Hukum, Ekonomi, dan Pembangunan Daerah serta Kesehatan.

Dalam proses pendidikan, setiap Ilmu yang dipelajari memiliki luaran yang berbeda sehingga kompetensi yang dibangun sebuah lulusan suatu program studi akan berbeda dengan program studilainnya.

Hubungan Masyarakat adalah sebuah Ilmu yang sekaligus sebagai sebuah profesi. Dia mempunyai ranah yang menjadi bidang kerja secara pasti, mempunyai lembaga yang secara khusus mengajarkan Ilmu dalam bidang kerjanya mulai dari tingkatan Diploma 3 (D3) sampai tingkat Doktor (S3), juga memiliki organisasi profesi sekaligus kode etik yang terkait dengan ranah atau bidang kerjanya.

Berdasar pertimbangan pendidikan dan kompetensi yang dibangun oleh pendidikan dan latarbelakang kellmuan di perguruan tinggi dari pegawai Humas pemerintah, maka jelas bahwa sekalipun mayoritas pendidikan tinggi akan tetapi pegawai Humas pemerintah tersebut belum bisa menjadi sumber daya manusia di bidang keHumasan, dengan pemikiran bahwa yang disebut dengan sumber daya manusia adalah mereka yang memenuhi kualifikasi persyaratan (kemampuan) di bidang Humas.

Disadari bahwa pendidikan formal bukan satu-satunya penentu produktivitas seseorang. Pengembangan produktivitas pegawai bisa juga dilakukan melalui pendidikan non formal yang oleh Manan diartikan sebagai "apa saja kegiatan yang terorganisasi di luar kerangka sekolah formal atau sistem universitas yang ada yang bertujuan untuk mengkomunikasikan gagasangagasan tertentu, pengetahuan, keterampilanketerampilan, sikap-sikap dan praktik-praktik sebagai jawaban terhadap kebutuhan yang telah ditentukan terlebih dahulu." (1988: 32), Bentuk pendidikan non formal tersebut adalah pelatihan.

Pendidikan non formal (pelatihan) yang diterima pegawai Humas pemerintah di daerah kajian menunjukan kondisi sebagai berikut:

Gambar 3 menunjukkan bahwa 70\% atau sebagian besar pegawai Humas pemerintah di daerah kajian belum mengikuti pelatihan yang terkait dengan bidang kerjanya atau hanya $30 \%$ yang sudah memperoleh pelatihan terkait bidang kerjanya.
Gambar tiga juga bisa diartikan bahwa dari lima (5) tahapan pengembangan Sumber Daya Manusia dari Dreyfrus, tidak satupun dikembangkan atau dijalankan padahal level pertama yang disebut dengan level pemula sesungguhnya demikian penting untuk dilaksanakan terkait dengan pengembangan kinerja karyawan, dalam level dasar ini pegawai seharusnya diberi pengertian dan pemahaman atas gambaran yang terkait dengan pekerjaan baru mereka.

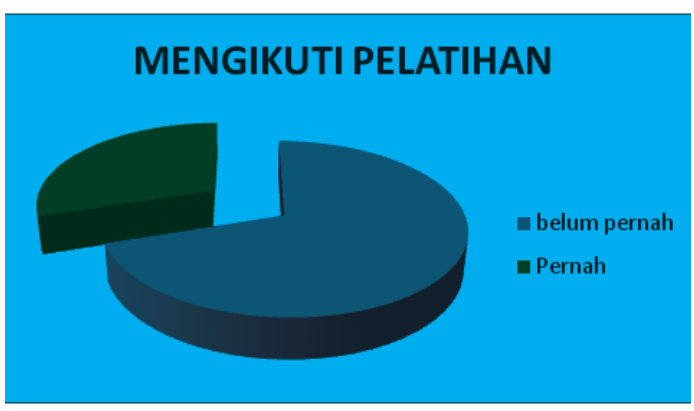

Gambar 3 Latar belakang pendidikan non formal pegawai Humas Pemerintah

Pentingnya pelatihan tahap pemula dalam pengembangan kinerja pegawai dikarenakan dalam tahap ini yang dilakukan adalah pembentukan sifat dan karakter serta tujuan utama kerja pegawai sebagai orang Humas secara detil.

Berdasarkan pendidikan formal yang dilihat dari latar belakang bidang kellmuan di perguruan tinggi dari pegawai Humas pemerintah daerah di wilayah kajian dan pendidikan formal atau pelatihan yang dijalani pegawai Humas pemerintah daerah di wilayah kajian maka tampak bahwa kedua aspek tersebut kurang mendukung bagi produktivitas atau kinerja Humas pemerintah daerah.

Pengembangan pegawai dilakukan untuk menghasilkan pengetahuan dan kemampuan baru dan bahkan kerangka kerja baru dari pemahaman dan pendidikan kejuruan, pengembangan juga bisa dilakukan melalui pembimbingan dan pemberian secara langsung oleh orang yang sudah atau lebih berpengalaman atau ahli, dan ini bisa diperoleh secara langsung di tempat kerja, ini berarti bahwa aspek waktu kerja atau pengalaman langsung seorang pegawai menjadi penting diperhatikan.

Data mengenai pengalaman kerja pegawai Humas Pemerintah di wilayah kajian ditunjukkan melalui Gambar 4. 


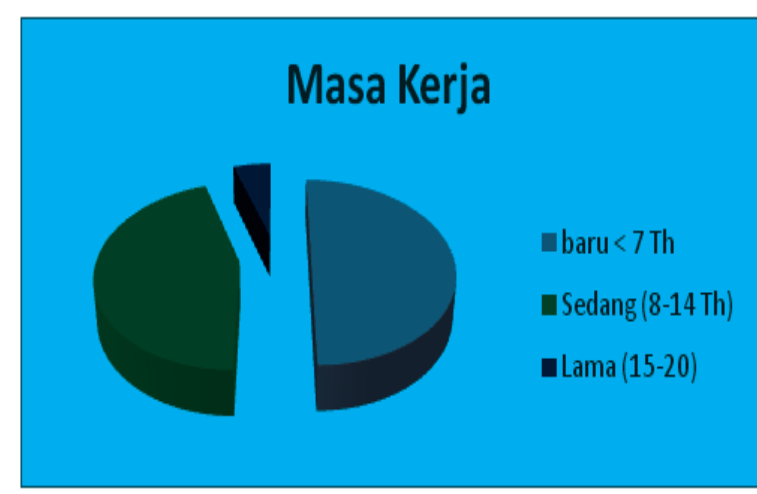

Gambar 4 Masa Kerja Pegawai Humas Pemerintah

Berdasarkan rangkaian data mengenai pendidikan formal, pendidikan non formal (pelatihan) serta masa kerja maka dapat disimpulkan bahwa pegawai di bagian Humas pada Pemerintah daerah kabupaten di wilayah kajian pada kebanyakan merupakan pegawai yang belum lama dan miskin dengan pelatihan juga kebanyakan tidak berlatar belakang kellmuan yang sesuai dengan bidang kerjanya.

Melihat latar belakang seperti ini, maka akan menjadi sulit bagi pimpinan yang ada di daerah kajian untuk mengharapkan kinerja yang baik dari pegawai Humas terlebih dengan munculnya inovasi-inovasi baru terkait dengan perbaikan di bidang kerjanya. Pekerjaan yang dilakukan biasanya hanya akan mengandalkan kerja yang bersifat rutinitas, sebuah kerja yang hanya melahirkan asal jadi atau terlaksana, dan miskin dengan prestasi.

Salah satu karakteristik dari sebuah aktivitas professional adalah terkait dengan ranah atau bidang kerja. Berdasarkan Gold paper IPRA, bidang kerja dari orang Humas mencakup atas:

"Memberi koseling; Membuat analsis isi dan kecenderungan masa depan; Riset sikap, pendapat dan harapan; Membina dan menciptakan komunikasi dua arah; Mencegah konflik; Meningkatkan rasa saling hormat; Melakukan penyerasian kepentingan; Meningkatkan pengalaman itikad baik lembaga; Memperbaiki hubungan industrial; Menarik calon tenaga yang baik; Memasyarakatkan produk dan layanan; Mengusahakan perolehan laba maksimal; Menciptakan identitas; Memupuk minat mengenai masalah-masalah nasional maupun internasional; Meningkatkan pengertian mengenai demokrasi”.

Pekerjaan Humas pemerintah di Indonesia secara tegas diatur melalui Per-aturan Mentri Pendayagunaan Aparatur Negara No: 12/M. PAN/08/TAHUN 2007 dalam ruang lingkup Humas yang mencakup atas: (1) penyampaian pesan \& penciptaan opini publik, (2) komunikasi internal eksternal guna memperoleh manfaat bersama bagi lembaga dan pemangku kepentingan, (3) melaksanakan fungsi manajemen pemerintahan, (4) membangun citra organisasi, pemerintah, bangsa dan negara.

Aturan ini kemudian diterjemahkan oleh pemerintah daerah masing-masing, sehingga walaupun sumbernya sama, pada akhirnya dalam beberapa hal ada yang berbeda di antara satu pemerintah daerah dengan pemerintah daerah lainnya. Akan tetapi secara umum tugas Humas di pemerintah daerah bisa ditunjukkan dengan temuan seperti berikut:

Berdasarkan struktur keorganisasian, hubungan masyarakat di wilayah kajian berada pada level bagian, yang dipimpin oleh seorang kepala yang disebut sebagai kepala bagian, selanjutnya bagian inipun membawahi beberapa sub bagian dengan tugas pokok yang berbeda.

Secara umum tugas pokok Bagian Hubungan Masyarakat di wilayah kajian berkaitan dengan "menyelenggarakan penyusunan, perumusan kebijakan dan pengolahan informasi, penyebarluasan informasi, dokumentasi, pelaksanaan kegiatan dan acara bersifat protokoler, penyelenggaraan persandian dan peralatan sandi tingkat kabupaten.

Berdasarkan hasil penyebaran angket, mengenai lima pekerjaan yang paling banyak atau sering dilakukan pegawai yang jadi responden di bagian keHumasan pada wilayah kajian adalah sebagai berikut: Paparan tertulis mengenai kebijakan, Menulis rilis, Update internet, Protokol Bupati, Protokol wakil, protokol setda, Membuat Naskah pidato, Fotografi, Mengkliping informasi dari media cetak terkait pemerintah dan pemerintahan serta pembangunan, Update data, SMS gateway, perbaiki jaringan, Penyunting tulisan ke luar, pengelola barang, update web, verifikasi sms yang masuk, melakukan pengelolaan (pengadministrasian) surat masuk, menyusun 
Rencana Kerja dan Anggaran bagian, liputan lapangan, gunting berita.

Jika lima pekerjaan yang paling banyak dikerjakanoleh petugas Humas dalamkeseharian mereka diklasifikasikan, maka pekerjaan di Humas pemerintah daerah paling banyak terkait dengan pekerjaan penulisan baik penulisan yang berhubungan dengan media baik media masa maupun media sosial serta penulisan yang tidak terkait dengan media, sedangkan pekerjaan kedua terbanyak dilakukan terkait dengan event; baru kemudian pekerjaan yang terkait dengan

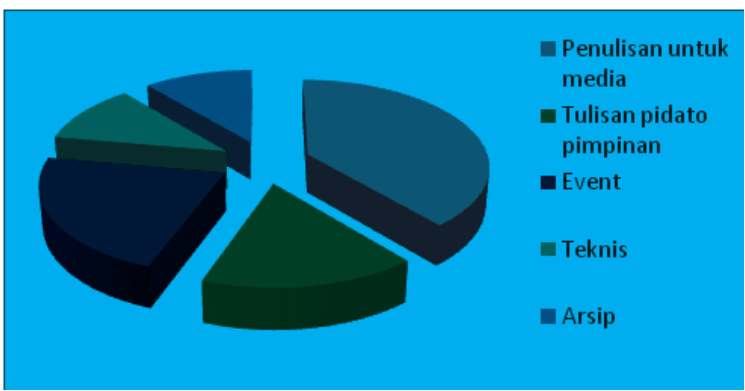

Gambar 5 Aktivitas Humas di Pemerintah

pendokumentasian dan teknis.

Berdasarkan klasifikasi lingkup pekerjaan, hasil penelitian secara beruurutan menunjukan kondisi seperti tampak pada Gambar 5

Hal yang bisa disimpulkan dari klasifikasi pekerjaan pegawai Humas Pemerintah di wilayah kajian memperlihatkan bahwa sampai saat ini, tugas utama Humas pemerintah lebih banyak berhubungan dengan media (wartawan), baru kemudian pekerjaan yang terkait dengan penyelenggaraan event, dan arsip serta teknis penunjang kegiatan Humas Pemerintah Daerah.

Hasil kerja secara efisien dan efektivitas pekerjaan seorang pegawai selanjutnya disebut kinerja. Hasil kerja yang dicapai seorang pegawai secara secara konsep terbagi atas tiga, yaitu hasil kerja di bawah standar yang ditentukan, hasil kerja yang sesuai dengan standar yang ditentukan serta hasil kerja yang berada di atas standar yang ditentukan.

Pencapaian hasil kerja pegawai Hubungan masyarakat di pemerintah daerah, menghasilkan tingkat kepuasan dan ketidakpuasan pimpinan. Pencapaian tingkat kepuasan pimpinan biasanya diikuti dengan pujian pimpinan terhadap pegawai Humas, sementara ketidakpuasan atau kekecewaan pimpinan terhadap hasil kerja pegawai akan diikuti dengan teguran pimpinan terhadap pegawainya.

Prestasi pegawai yang diikuti dengan

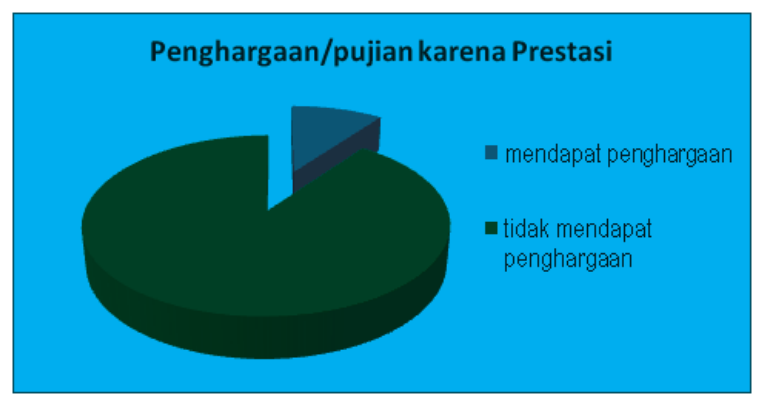

Gambar 6 Penerimaan pujian oleh pegawai karena prestasi kerja

pemberian penghargaan atau pujian oleh pimpinan kepada pegawai ditunjukan melalui Gambar 6.

Gambar 6 memperlihatkan bahwa kinerja pegawai Humas pemerintah miskin dengan prestasi, artinya demikian sedikit hasil dari kerja pegawai Humas dilingkungan pemerintah daerah yang mampu memuaskan para pimpinannya. Kondisi ini juga menimbulkan kekhawatiran munculnya kerja "asal jadi”, artinya sebuah kerja yang aktiitasnya hanya mendasarkan pada asal terlaksana.

Asumsi mengenai pekerjaan yang asal jadi ini juga didasarkan pada hasil kerja yang berada di bawah standar yang ditetapkan atau diharapkan. Bukti dari kinerja di bawah

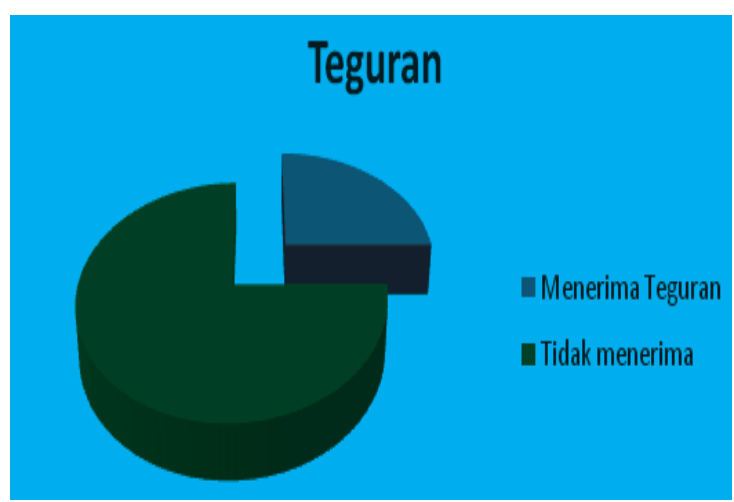

Gambar 7 Penerimaan teguran oleh Pegawai Humas Pemerintah

standar ditunjukan dengan teguran-teguran yang diterima pegawai dari pimpinannya. Data penerimaan teguran pimpinan oleh pegawai ditunjukan oleh Gambar 7.

Dengan melihat dua data terakhir menunjukkan bahwa kekecewaan pimpinan terhadap kinerja pegawai di bagian Humas pemerintah lebih tinggi dibanding dengan kepuasan pimpinan atas kinerja pegawai di bagian Humas pemerintah.

Secara umum kinerja pegawai Humas 


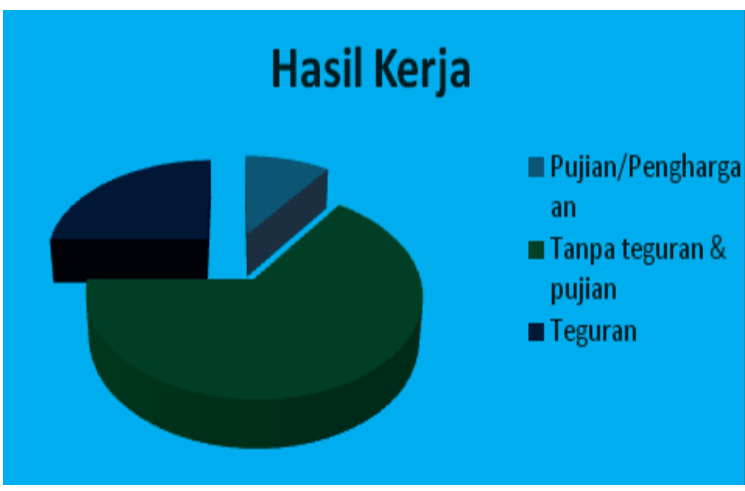

Gambar 8 Katagorisasi Hasil Kerja Humas Pemerintah

pemerintah yang dilihat dari penghargaan atau pujian dan teguran karena prestasi kerja ditunjukkan melalui Gambar 8.

Data yang ditunjukkan melalui Gambar 8 memperkuat asumsi bahwa pegawai di bagian Humas pemerintah lebih mengandalkan asal jadi atau asal terlaksana, hal ini ditunjukan dengan hasil kerja yang lebih banyak menerima teguran dan sangat jarang menerima pujian karena prestasi kerja. Ini berarti bahwa kekecewaan pimpinan dikaitkan dengan prestasi atau kinerja pegawai Humas pemerintah lebih banyak (tinggi) dibandingkan dengan kepuasan yang ditunjukan dengan pemberian pujian atau penghargaan pimpinan kepada pegawai.

\section{SIMPULAN}

Berdasarkan atas tujuan, data dan hasil analisa, maka ada beberapa hal yang menjadi simpulan dari penelitian ini, yaitu: Latar belakang pendidikan yang dilihat dari jenjangnya, pegawai Humas pemerintah cukup potensial karena memiliki pendidikan yang tinggi, sedangkan kalau dilihat dari latar belakang keIlmuan dan pelatihan yang diikutinya, menunjukan potensi yang rendah. (1) Bidang kerja Humas pemerintah di kabupaten lebih banyak terkait dengan penulisan untuk penyediaan informasi ke media, baru kemudian penulisan naskah pidato pejabat, dan aktivitas lainnya yang lebih terkait dengan penunjang kegiatan Humas pemerintah itu sendiri. (2) Kinerja Humas pemerintah yang dikaitkan dengan pujian atau penghargaan serta teguran yang diterima pegawai Humas pemerintah menunjukan bahwa teguran yang diterima pegawai terkait dengan pelaksanaan tugasnya lebih banyak dibanding dengan jumlah pujian.

Saran yang diberikan peneliti berdasarkan hasil penelitian ini di antaranya: (1) Penerimaan dan penempatan pegawai baru di Humas Pemerintah akan menjadi lebih baik apabila memperhatikan latar belakang keIlmuan pegawai, (2) Agar jenjang pendidikan pegawai yang sudah cukup tinggi memiliki kebermaknaan terhadap tingginya kinerja, disarankan agar dilakukan pengembangan pegawai melalui pelatihan (pendidikan nonformal) terkait dengan masing-masing bidang kerja utama pegawai di bagian Humas, dan (3) Terkait dengan bidang kerja saat ini, maka prioritas pengembangan tenaga Humas pemerintah adalah pelatihan penulisan Humas (PR writing) serta keterampilan komunikasi yang bersifat antar pribadi.

\section{DAFTAR PUSTAKA}

Anwar, K. (2014). Investasi pendidikan (suatu fungsi untuk pendidikan yang bermutu). Diakses dari http: //e-journal. iainjambi. ac. id/index. php/alfikrah/article/view/ $802 / 732$

Arabi Idid, S. (1998). Beauty, brain and brawn in public relations. Selangor: malindo Printers Sdn.

Black, S. \& Sharve, M. L. (1988). Ilmu hubungan masyarakat praktis. Jakarta: Intermasa.

Breakenridge, D. \& Deloughry, T. J. (2003). The new PR toolkit. Amerika: Publishing as Financial Times Prentice Hall.

Greener, T. (1990). Kiat sukses public relations. Jakarta: Bumi Aksara

Kompas, 18 Desember 2006

Manan. (1988). Dasar-dasar sosial budaya pendidikan. Jakarta: P2LPTK

Mitchell \& Larson. (1987). People in organizations, an introduction to organizational behavior. McGraw-Hill

Nasution. (1992). Metode penelitian naturalistik kualitatif. Bandung: Tarsito

Rahmat, A. (2000). Tesis, pengaruh komitmen dan aksesibilitas informasi terhadap 
produktivitas dosen di fakultas ilmu komunikasi. Bandung: Fakultas Ilmu Komunikasi Universitas Padjadjaran.

Rahmat, A. (2008). Desertasi, model pengembangan pendidikan pertanian melalui radio komunitas untuk pemberdayaan petani transmigran lokal (kausu di kabupaten sumedang). Bandung: Fakultas Ilmu Komunikasi Universitas Padjadjaran.

Setiawan, E. (2009). Peranan humas dalam pembangunan citra institusi. Diakses dari http: //www. academia.
edu/23549678/Peranan Humas dalam Pembangunan_Reputasi_atau_Citra Institusi

Smith, R. (2005). Strategic planning for public relations. London: Lawrence Erlbaum Associates.

Sullivan. (2000). Dinas penerangan yang bertanggung jawab, panduan internal. Amerika Serikat: Kantor Program Informasi Internasional, Departemen Luar Negeri.

Sparks, C. (2007). Globalization, development and mass media. Sage Publications 